Biskupski might have added a little rouge to his pale, albeit very well written portrayal of Retinger's political career. The Pole was a fascinating personality, and given that intrigue was his forte, the reader is left wanting more about his personal life. Retinger had several affairs and a tumultuous family life. He participated in hundreds of meetings with important political figures, but the book has no photos. This is a detailed study for experts on Polish and European diplomacy.

SHELDON ANDERSON Miami University, Ohio

\title{
Mordechaj Chaim Rumkowski-Wahrheit und Legende: "Meine jüdische Seele fürchtet den Tag des Gerichts nicht.” By Monika Polit. Trans. Heidemarie Petersen, Jürgen Hensel, and Małgorzata Sparenberg. Osnabrück: fibre Verlag, 2017. 271 pp. Bibliography. Index. Illustrations. Photographs. €29.80, paper. doi: 10.1017/slr.2018.226
}

Decades have passed, and still the figure of Mordechaj Chaim Rumkowski looms over both historical and fictional representations of the Łódź ghetto. For many, he remains a man decidedly self-interested, mean-spirited, ethically tainted, an object of scorn. But is the picture complete? In a calm tone, and with balanced appreciation for the sensitivity of the topic, the author succeeds in drawing a more accurate and nuanced picture of the man than commonly assumed. Most usefully, she has brought overlooked archival sources to light, rendering depth to our understanding of him as a historical figure.

Rumkowski, she is convinced, is best viewed over the course of a lifetime, with consideration of his historical role as controversial leader of the Jewish community in the ghetto enriched by an understanding of the broader arc of his career. Born in 1877 in Ilino, in Belorussia, Rumkowski migrated to Eódź in 1892. After the turn of the century, he had established himself as a small manufacturer, married, and commenced his lifelong activities as an activist in local institutions of Jewish social welfare. The author reveals Rumkowski to have been a man embedded within the affectionate circle of his family, including both his first wife (she would succumb to a fatal illness in 1937); his brother, Józef, to whom he was especially close; two sisters who settled in Russia; and a surviving nephew in Israel. In particular the text offers enriching details of Rumkowski's activities as an elected representative of the Jewish community during the interwar period, of his steady commitment to Zionism, and his sincere, if practically-minded devotion to the Jewish faith. As the author stresses, even in troubled times he was resolutely disinclined to place much hope in miracles or messianic intervention. The author also compellingly engages the unresolved topic of Rumkowski's controversial tenure as director of the Helenówek orphanage, the centerpiece of his career as a social activist within the community. In doing so, she highlights a little-known account dating from the early 1930s questioning the competence of the staff and alleging physical mistreatment of the youngsters under Rumkowski's care. Ms. Polit does well in bringing this sensitive material to light while judging it with fairness and cautious respect for the available evidence.

The text attends extensively to Rumkowski in his published writings and public appearances both prior to the war and inside the ghetto, identifying and providing analysis of his rhetorical styles, themes, and gestures. Fruitful attention is devoted to consideration of the surviving notebooks of the skilled Yiddish-language journalist, Szmul Rozensztajn. Rozensztajn proved a diligent observer, accompanying Rumkowski on his rounds, interviewing his closest confidants, transcribing his 
public speeches, and, most compellingly, offering occasional, behind-the-scenes glimpses of Rumkowski in the throes of anguish and worry. Perhaps most effectively, the author devotes considerable attention to an analysis and contextualization of a sample of some of the thousands of archived letters, including petitions for employment and financial assistance, as well as expressions of fond wishes on the occasion of life cycle events and holiday celebrations directed toward Rumkowski. Here authentic, if fawning expressions of regard for the leader mingle with revealing traces of the raw emotional toll of the ghetto on the daily life of the anxious population.

Readers will find tantalizing, if limited, discussion of the question of Rumkowski's knowledge of the fate of those deported from the ghetto. One discovers very brief, yet little-known glimpses of Rumkowski's appearance before the assembled mothers and fathers on the fateful occasion of his appeal for them to surrender their young children for deportation in September 1942 and of his troubled state of mind soon thereafter. Specialists will benefit from insights into Rumkowski's character revealed through citation and discussion of an unpublished report by one of the surviving youngsters whom Rumkowski adopted in the wake of the tragedy. A concluding chapter critiques some of the more prominent Polish and non-Polish efforts to portray Rumkowski in contemporary literature. The chapter will be essential reading, particularly for Englishspeaking readers unfamiliar with more salient Polish-language fiction on the topic.

Throughout, the author's aim is circumscribed and modest: examining the existing literature with a critical eye, supplementing the known body of source material with the results of her own wider search in archives in Poland and beyond, and in the process adding new texture to our understanding of Rumkowski as a man and his impact as leader of the Jewish community in the ghetto.

GORDON J. HORWITZ

Illinois Wesleyan University

Ethnic Germans and National Socialism in Yugoslavia in World War II. By Mirna Zakić. Cambridge: Cambridge University Press, 2017. xii, 298 pp. Notes. Bibliography. Glossary. Index. Maps. \$35.77, hard bound.

doi: 10.1017/slr.2018.227

Drawing upon Serbian and German sources, Ethnic Germans and National Socialism in Yugoslavia in World War II is a detailed, deeply-researched regional study of how ethnic Germans in the Yugoslav Banat, a borderland region between Serbia, Romania, and Hungary, became nationalized and Nazified before and during the Second World War.

Ethnic Germans, or Volksdeutsche, played a central yet complicated role in the Third Reich's expansionist policies and occupied territories. As Zakić describes, ambiguities in German racial theory meant that policymakers had no clear directives on the place of ethnic Germans in the larger German nation or the political fabric of the Third Reich. Indeed, despite their shared language and culture, most Nazi-occupying forces mistrusted ethnic Germans to govern themselves. But Banat Germans, Zakić suggests, proved an important exception: they became "junior partners" (3) to their Nazi bosses, trusted to administer their own region and implement Nazi policy in their region and the broader Yugoslav region. By slowly walking the reader through the local history of the interwar and wartime period, Zakić explores the layers of collaboration and complicity that emerged, showing how, with each passing month and year, Volksdeutsche agendas coalesced with the ideological and pragmatic ambitions 